\title{
Silver nanoparticle based alcohol sensor manufacturing training for detection of halal drinks
}

\section{Pelatihan pembuatan sensor alkohol berbasis nanopartikel perak untuk deteksi kehalalan minuman}

\author{
Chresiani Destianita Yoedistira', Muhammad Hilmi Afthoni', Rokiy Alfanaar ${ }^{2}$ \\ ${ }^{1}$ Departemen Farmasi, ${ }^{2}$ Departemen Kimia, Fakultas Sains dan Teknologi, Universitas Ma Chung Villa Puncak Tidar Blok N \\ No.1, Malang, 65151, Indonesia
}

\begin{abstract}
ARTICLE INFO
Received: 2020-12-07

Revised: 2021-02-12

Accepted: 2021-08-06

Keywords:

Chemical censor, Halal, Nanoparticle, Training

\section{ABSTRACT}

Nowadays, halal drinks are one of the sectors that get the attention of various parties. Alcohol in beverages is important in determining the halalness of a beverage. Halal detection can be done using chemical sensors. In the Pharmacy Department, knowledge of analysis using sensors is rare. Therefore, this community service program was carried out to introduce qualitative methods of quick and simple alcohol analysis. The participants are students of the Pharmacy Department of STIKES Anwar Medika in Sidoarjo City. Participants are communities engaged in the health sector who have an interest in halal and how to make sensors for halal testing. This program is implemented by making a video on how to make a chemical sensor for alcohol detection. The chemical sensor is a paper-immobilized colloidal silver-based chemical sensor which is easy to apply in various conditions. Based on the results of the color change produced on the filter paper, from green to bluish which indicates that the food or beverage sample contains alcohol. Based on the questionnaire, participants expressed satisfaction with the increase in knowledge about additional tools that are easy and fast to detect alcohol.
\end{abstract}

(C)2021 Published by University of Merdeka Malang. This is an open access article distributed under the CC BY-SA 4.0 license (https://creativecommons.org/licenses/by-sa/4.0/)

How to cite: Yoedistira, C. D., Afthoni, M. H., \& Alfanaar, R. (2021). Silver nanoparticle based alcohol sensor manufacturing training for detection of halal drinks. Abdimas: Jurnal Pengabdian Masyarakat Universitas Merdeka Malang, 6(4), 613-619. https://doi.org/10.26905/abdimas.v6i4.5124

\section{PENDAHULUAN}

Indonesia merupakan negara dengan penduduk mayoritas penduduk menganuk kepercayaan Islam. Implikasi dari Besarnya jumlah Penganut Agama Islam di Indonesia, membuat negara Indonesia mendirikan LPPOM MUI yang bertugas untuk melakukan sertifikasi kehalalan suatu makanan atau minuman (Faridah, 2019). Sertifikat halal ini akan melekat pada kemasan makanan atau minuman yang beredar di Indonesia (LPPOM Majelis Ulama Indonesia, 2015) .

Pada kenyataannya tidak semua makanan atau minuman sudah dilengkapi dengan sertifikasi kehalalan dari LPPOM MUI. Tidak adanya sertifikat halal pada kemasan makanan atau minuman dapat 
ABDIMAS: Jurnal Pengabdian Masyarakat Universitas Merdeka Malang

Volume 6, No. 2, May 2021: 613-619

menimbulkan kecemasan bagi konsumen. Tidak adanya sertifikat halal ini pula memerlukan suatu pengecekan yang lebih detail mengenai kehalalan minuman atau makanan tersebut. Contoh minuman tidak halal adalah minuman beralkohol yang secara kesehatan juga berbahaya karena dapat menimbulkan supresi pada sistem susunan saraf pusat bahkan sampai kehilangan kesadaran (Newbury-birch et al., 2009). Selain itu, konsumsi yang berlebihan untuk minuman beralkohol ini dapat menimbulkan kerusakan hati yang permanen atau sirosis (Gaviria et al., 2016). Bahaya mengkonsumsi alkohol kaitannya dengan metabolisme di dalam tubuh, alkohol dalam tubuh manusia, alkohol mengalami metabolisme fase pertama dengan bantuan sitokrom P450 (CYP450) menjadi Acetaldehyde (Jones, 2019). Acetaldehyde adalah senyawa turunan aldehid adalah senyawa yang dapat menyebabkan kerusakan pada jaringan sel manusia dengan kemampuan denaturasi protein, jika berikatan dengan DNA manusia akan bereaksi menghasilkan 1,N $\mathrm{N}_{2}$-propaodeoxyguanosine yang merupakan senyawa karsinogenik dan menyebabkan kanker (Cederbaum, 2012).

Alkohol merupakan kelompok senyawa organik dengan ciri khas adanya gugus hidroksi pada atom karbon. Alkohol merupakan senyawa yang suka deteksi dan untuk proses pendeteksian alkohol memerlukan instrumen yang cukup mahal seperti penggunaan Gas Chromatography-Mass Spectroscopy (Sharma, 2017), High Performance liquid chromatography - UV Vis (HPLC - UV Vis) (Nikelly \& Betz, 1987) Selain menggunakan instrumentasi yang mahal penggunaan instrument memerlukan waktu yang cukup Panjang, biaya perawatan instrumen yang tinggi sehingga dinilai tidak ekonomis dalam deteksi alkohol (Reis et al., 2009).

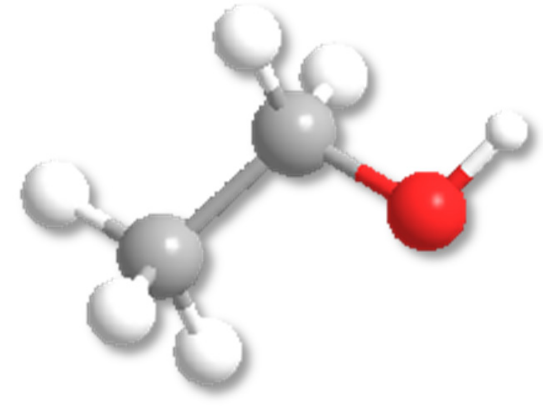

Gambar 1. Visualisasi struktur 3 dimensi Etanol

Deteksi alternatif alkohol merupakan salah satu hal yang ingin diketahui dan dikembangkan oleh kelompok belajar di STIKES Anwar Medika. STIKES Anwar Medika merupakan salah satu sekolah tinggi yang berkonsentrasi pada bidang kesehatan. STIKES ini mencari metode alternatif untuk mendeteksi alkohol tanpa harus menggunakan instrumentasi yang mahal. Dengan adanya permasalahan ini maka dicetuskanlah pengabdian dengan tujuan melatih membuat sensor kimia sebagai alternatif deteksi kehalalan minuman.

Persoalan yang dihadapi mitra adalah mencari alternatif cara deteksi kehalalan minuman berbasis deteksi alkohol. Dengan adanya masalah tersebut dirumuskan solusi melatih sensor kimia berbasis nanopartikel perak yang terimmobilisasi pada kertas sebagai altenatif teknologi deteksi alkohol pada minuman. Nanopartikel perak dipilih sebagai material yang digunakan dalam pengabdian karena termasuk material yang mudah disintesis (Shanmuganathan et al., 2019; Rafique et al., 2017; Natsuki, 2015). 
Pengabdian ini dilakukan dengan cara pelatihan secara dalam jaringan dengan cara pelatihan pembuatan sensor kimia berbasis nanopartikel perak.

\section{METODE}

Pelaksanaan pengabdian ini adalah melalui pelatihan dan subsitusi IPTEK. Pelatihan yang dilakukan adalah melatih pembuatan sensor kimia berbasis nanopartikel perak dan dilakukan adalah dengan cara mengganti deteksi alkohol yang secara umum menggunakan GC-MS menjadi sensor kimia.

\section{Rancangan kegiatan}

Tempat pelaksanaan pengabdian di STIKES Anwar Medika yang berlokasi di Jl. Parengan, Semawut, Balongbendo, Kecamatan Balong Bendo, Kabupaten Sidoarjo, Jawa Timur. Mitra yang terlibat adalah mahasiswa semester 1 dan 3. Peralatan atau fasilitas yang digunakan laboratorium sebagai tempat pembuatan materi (video) dan Microsoft Form sebagai media pengambilan data (kuesioner).

\section{Metode pelaksanaan}

Metode pelaksanaan pada pengabdian ini adalah dengan metode pengambilan survei dari partisipan, metode ini dinilai paling efektif dalam situasi pandemi COVID-19 dikarenakan harus ada pembatasan dalam pertemuan tatap muka.

Tabel 1. Jadwal dari pelaksanaan kegiatan

\begin{tabular}{|c|c|c|}
\hline Kegiatan & Tanggal Pelaksanaan & Deskripsi Kegiatan \\
\hline Pembuatan Video & 18 - 23 Juni 2020 & $\begin{array}{l}\text { Materi yang akan disampaikan kepada partisipan dikemas dalam ben- } \\
\text { tuk video, yang akan lebih mudah untuk pendistribusian materinya } \\
\text { dan lebih umum di kalangan mahasiswa yang sedang belajar melalui } \\
\text { daring. Pada video yang disampaikan meliputi alat dan bahan yang } \\
\text { digunakan untuk pembuatan sensor, cara membuat sensor kimia ser- } \\
\text { ta mengevaluasi apakah sensor tersebut dapat mengahasilkan warna } \\
\text { yang berbeda jika diujikan pada sampel yang mengandung alkohol. }\end{array}$ \\
\hline $\begin{array}{l}\text { Pengisian Kuisioner oleh } \\
\text { Peserta sebelum Materi }\end{array}$ & $25-30$ Juni 2020 & $\begin{array}{l}\text { Tahapan berikiutnya yang dilakukan adalah pengambilan data pen- } \\
\text { getahuan mahasiswa semester 1-3 mengenai sensor kimia yang salah } \\
\text { satunya dapat digunakan untuk menganalisis alcohol dalam makanan } \\
\text { atau minuman yang dikonsumsi dalam keseharian. Hal ini bertujuan } \\
\text { untuk mengukur pengetahuan mahasiswa, serta ketertarikan maha- } \\
\text { siswa terhadap materi yang akan disampaikan. }\end{array}$ \\
\hline $\begin{array}{l}\text { Pengamatan Video } \\
\text { Pelatihan }\end{array}$ & 25 - 30 Juni 2020 & $\begin{array}{l}\text { Pada proses ini dilakukan distribusi video materi yang telah dibuat ke- } \\
\text { pada mahasiswa, mahasiswa tersebut akan mengamati video tutorial } \\
\text { dan materi mengenai sensor kimia untuk menganalisis alcohol dalam } \\
\text { makanan atau minuman. }\end{array}$ \\
\hline $\begin{array}{l}\text { Pengisian Kuisioner Akhir } \\
\text { oleh Peserta setelah Materi }\end{array}$ & 25 - 30 Juni 2020 & $\begin{array}{l}\text { Setelah selesai pengematan video tutorial pembuatan dan materi di- } \\
\text { lakukan pengisian kuisioner dengan tujuan menganalisis pemahaman } \\
\text { mahasisiwa terhadap materi yang telah diberikan. }\end{array}$ \\
\hline
\end{tabular}


ABDIMAS: Jurnal Pengabdian Masyarakat Universitas Merdeka Malang

Volume 6, No. 2, May 2021: 613-619

\section{HASIL DAN PEMBAHASAN}

Alkohol yang dideteksi dalam pengabdian ini adalah etanol dengan rumus molekul $\mathrm{C}_{2} \mathrm{H}_{5} \mathrm{OH}$ yang merupakan alkohol yang paling banyak digunakan dalam minuman. Sensor kimia yang dirancang pada pengabdian ini sebagai subsitusi IPTEK deteksi alkohol memanfaatkan sifat alkohol yang dioksidasi akan menghasilkan aldehid dan peroksida sehingga mampu bereaksi dengan Leukometilen biru (Katafias et al., 2010) menghasilkan perubahan warna yang bisa diamati oleh mata. Leukometilen biru yang digunakan berasal dari reaksi Metilen biru dengan nanopartikel perak (Afthoni et al., 2018).<smiles>CN(C)c1ccc2c(c1)Sc1cc(N(C)C)ccc1N2</smiles>

Gambar 2. Struktur Leucometilen biru

Pelatihan pembuatan sensor kimia berbasis nanopartikel perak ini dilakukan secara dalam jaringan karena kendala adanya pandemi COVID-19. Pelatihan dilakukan dengan cara pembuatan video dan dilakukan korespondensi dengan pihak mitra. Sehingga metode ini adalah metode yang paling efektif untuk masa pandemi ini (Batubara et al., 2021; Gogali et al., 2020; Setiawan et al., 2020). Video pelatihan berisi tahapan yang dilakukan untuk menghasilkan sensor kimia untuk deteksi kehalalan minuman. Video pelatihan dilakukan pada Laboratorium Kimia Farmasi Fakultas Sains dan Teknologi Universitas Ma Chung.

Tahap pertama pelatihan dalam video ini adalah penjelasan mengenai alat dan bahan yang akan digunakan dalam pelatihan (Gambar 3). Tahap ini penting karena setiap alat dan bahan memiliki fungsi yang beberapa fungsinya tidak dapat diganti dengan alat atau bahan lain. Pemilihan video sebagai media pelatihan juga mempertimbangkan kerunutan dalam penjelasan alat dan bahan yang digunakan karena merupakan bagian kritis dalam pembuatan sensor kimia ini. Dimana alat dan bahan untuk pembuatan sensor kimia ini meliputi kertas saring, mikropipet, timbangan analitik, serta alat gelas lainnya seperti labu ukur dan tabung reaksi. Selain dari pada itu bahan yang diperlukan dalam pembuatan senor kimia ini adalah seperti Perak Nitrat, Kalium Dikromat, Natrium Sitrat, Methylene Blue, dan Aquadest (Gambar 4).
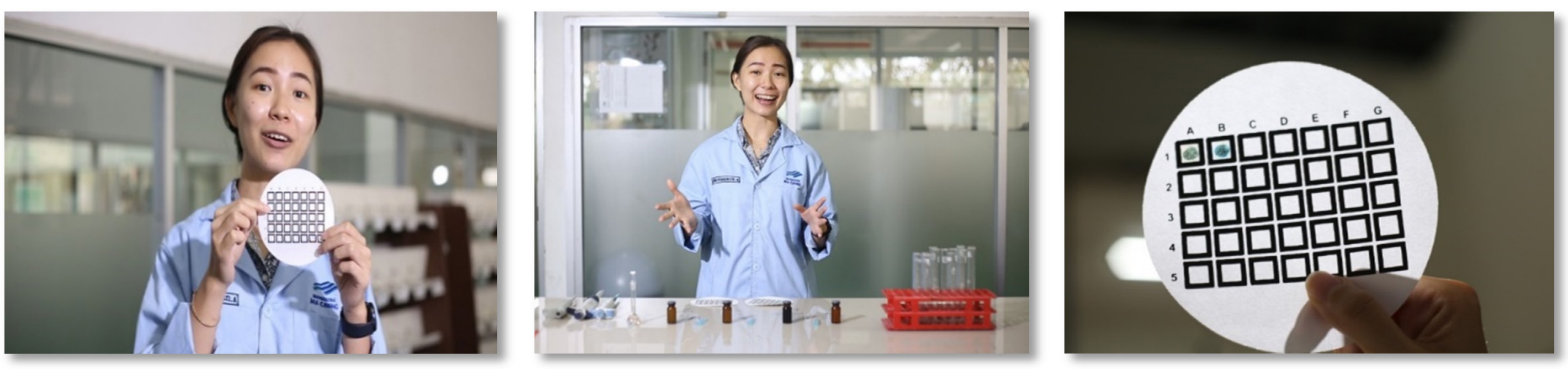

Gambar 3. Tahap pengenalan alat

Gambar 4. Pengenalan bahan yang digunakan dalam pembuatan sensor kimia

Gambar 5. Hasil sensor kimia berbasis nanopartikel perak 


\section{Silver nanoparticle based alcohol sensor manufacturing training for detection of halal drinks}

Chresiani Destianita Yoedistira, Muhammad Hilmi Afthoni, Rokiy Alfanaar

Setelah menjelaskan mengenai alat dan bahan yang digunakan maka dilanjutkan dengan reaksi reduksi perak untuk menghasilkan nanopartikel perak. Nanopartikel perak ini yang akan digunakan untuk mengubah Metilen biru menjadi Leucometilen biru yang dapat bertindak sebagai sensor. Untuk mempermudah pengamatan kinerja sensor dilakukan immobilisasi sensor kimia pada kertas saring.

Tahapan dalam pembuatan sensor ini dijelaskan secara runut karena ketidakrunutan dalam sintesis akan tidak menghasilkan sensor kimia yang diharapkan. Tahapan pertama dalam pembuatan sensor ini adalah reduksi perak nitrat dengan Natrium Sitrat demi menghasilkan nanopartikel perak. Metode ini disebut lazim disebut dengan metode Turkevich yang juga mampu digunakan untuk mendapat nanopartikel emas (Kimling et al., 2006). Setelah menghasil nanopartikel perak, larutan ditambahkan dengan Metilen biru untuk menghasilkan Leucometilen biru. Hasil ini kemudian ditambahkan dengan Kalium Bikromat yang akan bertindak sebagai oksidator alkohol. Sensor yang telah diperoleh kemudian diimmobilisasi pada kertas saring.

Kertas saring yang telah mengimobilisasi sensor kimia kemudian ditambahkan minuman yang memiliki kandungan alkohol. Penambahan dilakukan pada dua bagian yang berbeda dimana pada bagian A1 tidak ditambahkan alkohol dan pada A2 ditambahkan alkohol. Pemisahan ini bertujuan agar mitra dapat melihat perbedaan warna yang dihasilkan. Setelah ditambahkan terjadi perubahan warna yang ditunjukkan pada Gambar 5. Perubahan warna ini disebabkan Leucometilen biru yang terbentuk bereaksi dengan aldehid yang dihasilkan oleh oksidasi alkohol.

Metode pendeteksian alkohol dengan menggunakan sensor berbasis kimia ini kami harapkan dapat menjadi metode yang sederhana untuk dapat diaplikasikan dalam keseharian. Kemudian hasil yang kami dapatkan dari responden mitra kami mengenai pelatihan pendeteksian alkohol berbasis kimia ini juga mendapatkan respon yang baik hal ini dapat dibuktikan dengan hasil survei akhir yang kami lakukan. Dimana dalam hasil survei tersebut mitra menunjukkan bahwa metode yang kami berikan cukup mudah untuk diikuti derta sangat menambah pengetahuan mereka akan sensor yang dapat dibuat secara sederhana. Selain dari pada itu, dalam pelatihan ini tidak membutuhkan instrumentasi yang rumit serta menambahkan pengetahuan mereka akan sensor kimia, dimana pengetahuan ini mulai popular di kalangan farmasi dan alat kesehatan. Namun, tidak semua lembaga Pendidikan dapat menyisipkan pengetahuan mengenai sensor ini dikarenakan keterbatasan tenaga ahli.

Selain dari pada itu, sensor kimia untuk mendeteksi alkohol dalam minuman sehari-hari yang kita konsumsi menjadi alternatif yang sangat baik dikarenakan sensor kimia ini dapat mendeteksi secara cepat, mudah, dan sederhana (Hidayat et al., 2020). Sehingga dapat memastikan secara cepat kehalalan dari setiap minuman yang dikonsumsi serta dapat digunakan sebagai instrumentasi penjaminan mutu untuk konsumen.

\section{SIMPULAN DAN SARAN}

Pelatihan pembuatan sensor kimia untuk deteksi kehalalan minuman telah berhasil dilaksanakan dengan respon yang baik dari mitra STIKES Anwar Medika Sidoarjo. Dari hasil sensor yang dibuat pada pelatihan ini berbahan dasar nanopartikel perak yang digunakan untuk mengubah Metilen biru menjadi Leucometilen biru. Adapun tujuan dari pengabdian ini telah tercapai yaitu mengenalkan metode analisis 
ABDIMAS: Jurnal Pengabdian Masyarakat Universitas Merdeka Malang

Volume 6, No. 2, May 2021: 613-619

sederhana dan cepat untuk dapat menganalisis alkohol pada makanan dan minuman yang sehari-hari dikonsumsi, agar memberikan jaminan halal untuk masyarakat luas. Pada pengabdian ini ada kendala yang dihadapi yaitu perubahan sistem penyampaian meteri yang seharusnya dilakukan tatap muka dan tutorial langsung, dikarenakan adanya pandemi COVID-19 maka metode tersebut diubah menjadi metode daring.

Adapun saran yang dapat disampaikan adalah untuk melakukan pengabdian ini dengan sampel makanan atau minuman yang diuji lebih banyak sehingga dapat mengetahui apakah bahan tambahan lain dalam makanan maupun minuman dapat mempengaruhi hasil pewarnaan yang dihasilkan.

\section{Ucapan Terima Kasih}

Ucapan terima kasih penulis tujukan kepada LPPM Universitas Ma Chung yang telah membiayai pengabdian ini melalui skema IPTEK bagi Masyarakat pada hibah Ma Chung Abdimas Grant pada tahun 2020. Terima kasih juga tertuju kepada pihak STIKES Anwar Medika yang telah memberikan kesempatan berbagi ilmu kepada mereka dan juga kepada Laboratorium Kimia Farmasi yang telah menyediakan fasilitas untuk pembuatan sensor kimia untuk deteksi kehalalan minuman.

\section{Daftar Pustaka}

Afthoni, M. H., Wahjudi, M., \& Kuswandi, B. (2018). Scanometric assay for Charantin in Bitter Melon (Momordica charantia) extract based on immobilized Silver Nitrate and Methylene Blue as Colorimetric Paper. Journal of Food Chemistry \& Nanotechnology, 04(02), 27-32. https://doi.org/10.17756/jfcn.2018-054

Batubara, S., Wahyuni, S., Hariyanto, E., \& Lubis, A. (2021). Webinar Menangkal Cyberporn pada Internet dan Android memanfaatan add ons dan aplikasi antipornografi parental control di SMA Panca Budi. Jurnal Abdimas BSI: Jurnal Pengabdian kepada Masyarakat, 4(1), 164-173. https://doi.org/10.31294/jabdimas.v4i1.9048

Cederbaum, A. I. (2012). Alcohol metabolism. Clinics in Liver Disease, 16(4), 667-685. https://doi.org/10.1016/j.cld.2012.08.002

Faridah, H. D. (2019). Halal certification in Indonesia; history, development, and implementation. Journal of Halal Product and Research, 2(2), 68. https://doi.org/10.20473/jhpr.vol.2-issue.2.68-78

Gaviria C., M. M., Correa Arango, G., \& Navas N., M. C. (2016). Alcohol, cirrhosis, and genetic predisposition. Revista Colombiana de Gastroenterologia, 31(1), 27-35. https://doi.org/10.22516/25007440.70

Gogali, V. A., Tsabit, M., \& Syarief, F. (2020). Pemanfaatan webinar sebagai media komunikasi pemasaran di masa pandemi Covid-2019 (Studi kasus webinar BSI Digination "How to be a Youtuber and an Entrepreneur"). Cakrawala-Jurnal Humaniora, 20(2), 182-187. https://doi.org/10.31294/jc.v20i2.9211

Hidayat, M. A., Maharani, D. A., Purwanto, D. A., Kuswandi, B., \& Yuwono, M. (2020). Simple and sensitive paper-based colorimetric biosensor for determining total polyphenol content of the green tea beverages. Biotechnology and Bioprocess Engineering, 25(2), 255-263. https://doi.org/10.1007/s12257-019-0299-8 


\section{Silver nanoparticle based alcohol sensor manufacturing training for detection of halal drinks}

Chresiani Destianita Yoedistira, Muhammad Hilmi Afthoni, Rokiy Alfanaar

Jones, A. W. (2019). Alcohol, its absorption, distribution, metabolism, and excretion in the body and pharmacokinetic calculations. Wiley Interdisciplinary Reviews: Forensic Science, 1(5).

https://doi.org/10.1002/wfs2.1340

Katafias, A., Lipińska, M., \& Strutyński, K. (2010). Alkaline hydrogen peroxide as a degradation agent of methylene blue-kinetic and mechanistic studies. Reaction Kinetics, Mechanisms and Catalysis, 101(2), 251-266. https://doi.org/10.1007/s11144-010-0234-7

Kimling, J., Maier, M., Okenve, B., Kotaidis, V., Ballot, H., \& Plech, A. (2006). Turkevich method for gold nanoparticle synthesis revisited. Journal of Physical Chemistry B, 110(32), 15700-15707. https://doi.org/10.1021/jp061667w

LPPOM Majelis Ulama Indonesia. (2015). Ketentuan kelompok produk bersertifikat halal MUI Revisi 1. Nomor: SK 11/Dir/LPPOM MUI/II/14-Rev1, 8917(51). https://e-Ippommui.org/documents/ SK11.II.2014_Ketentuan_Kelompok_Produk_berSH_MUI_(revisi-1).pdf

Natsuki, J. (2015). A Review of silver nanoparticles: Synthesis methods, properties and applications. International Journal of Materials Science and Applications, 4(5), 325. https://doi.org/10.11648/j.jimsa.20150405.17

Newbury-birch, D., Walker, J., Avery, L., Beyer, F., Brown, N., Jackson, K., Lock, C. A., Mcgovern, R., Kaner, E., Mcardle, P., Ramesh, V., \& Stewart, S. (2009). Impact of Alcohol Consumption on Young People A Systematic Review of Published Reviews. January 2014, 1-66.

Nikelly, J. G., \& Betz, J. M. (1987). Determination of ethanol in alcoholic beverages by liquid chromatography using the UV detector. Journal of Chromatographic Science, 25(9), 391-394. https://doi.org/10.1093/chromsci/25.9.391

Rafique, M., Sadaf, I., Rafique, M. S., \& Tahir, M. B. (2017). A review on green synthesis of silver nanoparticles and their applications. Artificial Cells, Nanomedicine and Biotechnology, 45(7), 1272-1291. https://doi.org/10.1080/21691401.2016.1241792

Reis, A. V., Fajardo, A. R., Schuquel, I. T. A., Guilherme, M. R., Vidotti, G. J., Rubira, A. F., \& Muniz, E. C. (2009). Reaction of Glycidyl Methacrylate at the Hydroxyl and Carboxylic Groups of Poly(vinyl alcohol) and Poly(acrylic acid): Is this reaction mechanism still unclear? The Journal of Organic Chemistry, 74(10), 3750-3757. https://doi.org/10.1021/jo900033c

Setiawan, T. H., Aden, A., \& Rahman, A. N. (2020). Pelatihan Daring Teknologi Pembelajaran. Jurnal Pengabdian Kepada Masyarakat (JPKM)-Aphelion 1(01), 37-47.

http://www.openjournal.unpam.ac.id/index.php/JPKA/article/view/6904

Shanmuganathan, R., Karuppusamy, I., Saravanan, M., Muthukumar, H., Ponnuchamy, K., Ramkumar, V. S., \& Pugazhendhi, A. (2019). Synthesis of silver nanoparticles and their biomedical applications - A comprehensive review. Current Pharmaceutical Design, 25(24), 2650-2660.

https://doi.org/10.2174/1381612825666190708185506

Sharma, R. M. (2017). Forensic characterization of liquor samples by Gas Chromatography-Mass Spectrometry (GC-MS) - A review. Arab Journal of Forensic Sciences and Forensic Medicine, 1(6), 695-714. https://doi.org/10.26735/16586794.2017.011 